\title{
Phytoprotection
}

\section{The detection of Anaphes sp. nov. [Hymenoptera : Mymaridae], an egg parasitoid of the carrot weevil in Nova Scotia}

\author{
L.R.E. Hopper, J.-P.R. Le Blanc et G. Boivin
}

Volume 77, numéro 2, 1996

URI : https://id.erudit.org/iderudit/706103ar

DOI : https://doi.org/10.7202/706103ar

Aller au sommaire du numéro

Éditeur(s)

Société de protection des plantes du Québec (SPPQ)l

ISSN

0031-9511 (imprimé)

1710-1603 (numérique)

Découvrir la revue

Citer cet article

Hopper, L., Le Blanc, J.-P. \& Boivin, G. (1996). The detection of Anaphes sp. nov. [Hymenoptera : Mymaridae], an egg parasitoid of the carrot weevil in Nova Scotia. Phytoprotection, 77(2), 79-82. https://doi.org/10.7202/706103ar
Résumé de l'article

Les guêpes Anaphes victus (Huber) et Anaphes listronoti (Huber) [Hymenoptera : Mymaridae] parasitent 50\% des oeufs du charançon de la carotte, Listronotus oregonensis (Le Conte) [Coleoptera : Curculionidae] au Québec et en Ontario. Des essais de piégeage en Nouvelle-Ecosse de l'un ou l'autre de ces parasites en exposant des oeufs du charançon de la carotte n'ont pas réussi.

Cependant, 48 spécimens d'une nouvelle espèce de guêpe, Anaphes sp. nov. [Hymenoptera : Mymaridae], ont été capturés dans des champs de carotte (Daucus carota) en Nouvelle-Ecosse, en utilisant des carottes infestées en chambre de croissance par des oeufs du charançon de la carotte. Anaphes sp. nov. se distingue des autres parasites du charançon de la carotte par des caractéristiques de la paire d'ailes antérieure. Anaphes sp. nov. possède un rapport longueur : largeur plus grand que $7: 3$ pour l'aile antérieure alors que chez A. victus et $A$. listronoti, ce même rapport est plus petit que 6: 7 . 


\title{
Communication brève / Short Communication
}

\section{The detection of Anaphes sp. nov. [Hymenoptera : Mymaridae], an egg parasitoid of the carrot weevil in Nova Scotia}

\author{
Laura R.E. Hooper ${ }^{1}$, Jean-Pierre R. Le Blanc², and Guy Boivin ${ }^{3}$
}

Received 1995-10-20; accepted 1996-06-04

The wasps Anaphes victus (Huber) and Anaphes listronoti (Huber) [Hymenoptera : Mymaridae] parasitize $50 \%$ of the eggs of carrot weevil, Listronotus oregonensis (Le Conte) [Coleoptera : Curculionidae] in Quebec and in Ontario. Attempts to detect either of these egg parasites from exposed carrot weevil eggs in Nova Scotia were unsuccessful. However, 48 individuals of a new species of parasitic wasp, Anaphes sp. nov. [Hymenoptera : Mymaridae], were detected in carrot (Daucus carota) fields in Nova Scotia, using carrots infested in growth chambers with carrot weevil eggs. Anaphes sp. nov. is distinguishable from the other parasites of the carrot weevil by characteristics of the forewing. Anaphes sp. nov. has a forewing length : width ratio greater than $7: 3$ while $A$. victus and $A$. listronoti have a forewing length : width ratio of less than $6: 7$.

Hooper, L.R.E., J.-P.R. Le Blanc, and G. Boivin. 1996. Présence de I'Anaphes sp. nov. [Hymenoptera : Mymaridae], un parasite de l'oeuf du charançon de la carotte en Nouvelle-Écosse. PHYTOPROTECTION 77 : 79-82.

Les guêpes Anaphes victus (Huber) et Anaphes listronoti (Huber) [Hymenoptera: Mymaridae] parasitent $50 \%$ des oeufs du charançon de la carotte, Listronotus oregonensis (Le Conte) [Coleoptera : Curculionidae] au Québec et en Ontario. Des essais de piégeage en Nouvelle-Écosse de l'un ou l'autre de ces parasites en exposant des oeufs du charançon de la carotte n'ont pas réussi. Cependant, 48 spécimens d'une nouvelle espèce de guêpe, Anaphes sp. nov. [Hymenoptera: Mymaridae], ont été capturés dans des champs de carotte (Daucus carota) en Nouvelle-Écosse, en utilisant des carottes infestées en chambre de croissance par des oeufs du charançon de la carotte. Anaphes sp. nov. se distingue des autres parasites du charançon de la carotte par des caractéristiques de la paire d'ailes antérieure. Anaphes sp. nov. possède un rapport longueur: largeur plus grand que $7: 3$ pour l'aile antérieure alors que chez $A$. victus et $A$. listronoti, ce même rapport est plus petit que $6: 7$.

1. Department of Biology, Memorial University of Newfoundland, Science Bldg., Room S1083A, St. John's, Newfoundland, Canada A1B 3X9

2. A.D. Pickett Entomological Museum and Research Laboratory, Department of Biology, Nova Scotia Agricultural College, P.O. Box 550, Truro, Nova Scotia, Canada B2N 5E3. Author to whom correspondence should be addressed

3. Agriculture and Agri-Food Canada, Research Station, 430 Gouin Blvd., Saint-Jean-surRichelieu, Quebec, Canada J3B 3E6 
The carrot weevil, Listronotus oregonensis (Le Conte) [Coleoptera : Curculionidae] is an important pest of vegetable crops in the northeastern United States and Canada (Collins and Grafius 1986). In Canada, this pest attacks parsley (Pastinaca sativa L.) and celery (Apium graveolens L. var. duice) but is economically important only on carrots (Daucus carota L.), where up to $40 \%$ of the crop may be damaged if $L$. oregonensis is left uncontrolled (Boivin 1985; Perron 1971; Stevenson 1981). The carrot weevil was detected for the first time in 1992 in Nova Scotia (Le Blanc and Boivin 1993) where carrot production is increasing rapidly (Anonymous 1993).

Anaphes victus (Huber) and A. listronoti (Huber) [Hymenoptera: Mymaridae] are egg parasitoids which have a good potential as biological control agents against $L$. oregonensis. The former species is solitary, and the latter one is gregarious. Both species occur in eastern Canada and United States. Until now, these were the only parasitoids of carrot weevil eggs known and were collectively referred to as Anaphes sordidatus (Girault) (Boivin 1986); this latter species is presently considered to occur only in Wisconsin. These egg parasitoids have been identified as key factors in the control of the carrot weevil, being able to cause up to $50 \%$ mortality in field tests (Boivin 1986; Collins and Grafius 1986). In view of this fact and because $L$. oregonensis is a major pest in Ontario and Quebec, it was important to determine what parasitoids were affecting the eggs of the carrot weevil in Nova Scotia.

Carrots were infested with carrot weevil eggs in the laboratory by incubating adult carrot weevils with carrots in jars at $24^{\circ} \mathrm{C}$ under a 18-h light and 6-h dark photoperiod. With this technique, when ca. 300 carrot weevils (not sexed) were placed on four average size healthy carrots, about 50-300 eggs were laid over a period of $48 \mathrm{~h}$ on each carrot. The development of the weevil eggs was retarded by replacing the carrots every $2 \mathrm{~d}$ and refrigerating the infested carrots at $6^{\circ} \mathrm{C}$ until enough infested carrots were available for placement at the test sites. These eggs have been found to be acceptable by parasitoids and the development of the parasitoids is not affected (Traoré and Boivin, unpublished data).

During the late spring of 1994, six commercial carrot fields were selected as test sites near Great Village, Nova Scotia (lat. $45^{\circ} 25^{\prime} \mathrm{N}$, long. $63^{\circ} 36^{\prime} \mathrm{W}$ ). The sites were selected adjacent to the sites where weevils were detected the previous year (Le Blanc and Boivin 1993). Original sites of detection were not used because they were not currently sown to carrots due to crop rotation practices. Other significant carrot acreages are found near the New Brunswick border, in the vicinity of Oxford, Nova Scotia, (ca. $43 \mathrm{~km}$ due north of Great Village), where the main carrot processor is located.

At the end of each field, four $30 \mathrm{~cm}^{2}$ wooden canopies were installed near overwintering sites of weeds and leaf litter favourable to carrot weevils. The carrots were protected from desiccation at the test sites by using these wooden canopies. Every week, a carrot infested in the laboratory with carrot weevil eggs was placed under each weather-proof canopy. The carrots were collected from the field after $3 \mathrm{~d}$ of exposure and in most cases, up to $25 \mathrm{~L}$. oregonensis eggs were extracted from each carrot. Those eggs were incubated in polyethylene capsules (Boivin 1986) and the emergence of a weevil larva or a parasitoid was noted. This sampling was carried out each week from 29 April to 14 September, however, in two of the six commercial fields, monitoring carrots became useless because insect pest populations (including the carrot weevil) rose to a level requesting immediate insecticidal applications. Consequently the total egg potential of 12000 was reduced to 7200 and because the carrots were damaged, only 7014 eggs were properly incubated.

On 6 June 1994, the first parasitoid emerged from one of the eggs exposed on 25 May. Thereafter, several other parasitoids emerged every week, the last ones emerging 22 August (Table 1). For validation purposes, some of the emerged parasitoids were examined and identified. Only one species was found. This parasitoid species was identified by $\mathrm{Dr}$. J.T. Huber (Centre for Land and Biological Resources Research, Ottawa) as a new species of Anaphes. Several spe- 
Table 1. Emergence of Anaphes sp. nov. from field exposed carrot weevil eggs in Nova Scotia carrot fields, summer 1994

\begin{tabular}{llr}
\hline $\begin{array}{l}\text { Date of } \\
\text { encapsulation }\end{array}$ & $\begin{array}{l}\text { Date of } \\
\text { emergence }\end{array}$ & $\begin{array}{r}\text { Number of } \\
\text { parasitoids }\end{array}$ \\
\hline 25 May & 6 June & 1 \\
6 July & 15 July & 13 \\
12 July & 22 July & 1 \\
19 July & 29 July & 16 \\
26 July & 5 August & 2 \\
26 July & 8 August & 4 \\
4 August & 15 August & 3 \\
9 August & 22 August & 8 \\
\hline
\end{tabular}

cimens were retained at this location as voucher specimens and for future research. This new species can be distinguished from $A$. victus and $A$. listronoti by characteristics of the forewing. Anaphes sp. nov. has a forewing length: width ratio greater than $7: 3$ while $A$. victus and $A$. listronoti both have a forewing length : width ratio of less than $6: 7$ (J.T. Huber, personal communication). A total of 48 egg parasitoids emerged from the 7014 eggs incubated during the study. Of the 6966 remaining incubated eggs, about $95 \%$ yielded a carrot weevil grub. The peak parasitism was observed on eggs encapsulated on 19 July, when 16 parasitoids emerged on 29 July from three of the six fields. Because there were four carrots placed in each field, on each sampling occasion (25 eggs carrot ${ }^{-1}$ ) a simple percent parasitism can be calculated. It is obvious that many sampling occasions will result in no parasitism because eggs were made available before and after the optimal flight period of Anaphes spp. to maximize chances of detection. When the parasitoid was detected the percent parasitism ranged from $1.25 \%$ to $10.4 \%$. Readers are cautioned not to interpret this percent parasitism as a valid reflection of field conditions. Our artificial system was strictly aimed at parasitoid detection and not quantification. In the same perspective, the sex ratio of Anaphes sp. nov., based on the total number of detected individuals, was 26 $q: 22{ }^{\circ}$. Statistically, this ratio was not found to be significantly different from $1: 1\left(\chi^{2}=\right.$ 0.577, $\alpha=0.05$, and one d.f.), however, this should be validated under natural field conditions.

The carrot weevil has recently been introduced in Nova Scotia and is consequently not a native host of Anaphes sp. nov. The indigenous hosts of Anaphes sp. nov. in the Maritimes are presently unknown. The egg parasitoids $A$. victus and $A$. listronoti were not detected at the test sites as expected, although they may be present at densities not detectable in this experiment. This is unlikely, however, due to the large number of eggs observed. Our results (up to $10.4 \%$ parasitism with this artificial system) suggest that Anaphes sp. nov. could be an important natural mortality factor for the carrot weevil, Listronotus oregonensis, in Nova Scotia, as other Anaphes spp. were found to be in Quebec and in Ontario (up to $50 \%$ parasitism). Consequently its activity should be considered in the development of an IPM programme and perhaps inundation releases should be carried out wherever carrot weevils are detected in Nova Scotia, particularly in new sites of our increasing carrot production.

\section{ACKNOWLEDGEMENTS}

The authors thank Dr. J.T. Huber (Centre for Land and Biological Resources Research, Ottawa, Ontario, Canada) for taxonomical assistance, Ms. D. Thibodeau (Agriculture and Agri-Food Canada, SaintJean-sur-Richelieu, Quebec, Canada) and Mrs. A.D. Bowers (Nova Scotia Agricultural College, Truro, Nova Scotia, Canada) for insect rearing and egg incubation. 


\section{REFERENCES}

Anonymous. 1993. Nova Scotia Agricultural Statistics 1992. Vol. 27. 201 pp.

Boivin, G. 1985. Evaluation of monitoring techniques for the carrot weevil, Listronotus oregonensis [Coleoptera: Curculionidae]. Can. Entomol. 117 : 927-933.

Boivin, G. 1986. Anaphes sordidatus (Girault) [Hymenoptera: Mymaridae], an egg parasite of the carrot weevil, Listronotus oregonensis (Le Conte). Can. Entomol. 118: 393-394.

Collins, R.D., and E.J. Grafius. 1986. Biology and life cycle of Anaphes sordidatus [Hymenoptera: Mymaridae], on the carrot weevil [Coleoptera : Curculionidae]. Environ. Entomol. 15 : 927-933.
Le Blanc, J.-P.R., and G. Boivin. 1993. A note on the detection of the carrot weevil in Nova Scotia. Phytoprotection 74 : 113-115.

Perron, J.P. 1971. Insect pests of carrots in organic soil of southwestern Quebec with special reference to the carrot weevil, Listronotus oregonensis [Coleoptera : Curculionidae]. Can. Entomol. 103 : 1441-1448.

Stevenson, A.B. 1981. Carrot insects. Min. Agric. Food Ont. Factsheet 81-007, Agdex 258/605. 4 pp. 